УДК 821.161 .1

DOI: 10.18101/2305-459X-2019-4-49-53

\title{
ИЗУЧЕНИЕ ПОЭЗИИ Ю. ШЕВЧУКА В ШКОЛЕ
}

\section{(C) Колмакова Оксана Анатольевна}

доктор филологических наук, доцент кафедры русской и зарубежной литературы, Институт филологии и массовых коммуникаций, Бурятский государственный университет имени Д. Банзарова Россия, 670000, г. Улан-Удэ, ул. Смолина, 24 а

E-mail: post-oxygen@mail.ru

\section{() Мунгалова Анна Николаевна}

магистрант Института филологии, иностранных языков и массовых коммуникаций Бурятский государственный университет им. Д. Банзарова

Россия, 670000, г. Улан-Удэ, ул. Смолина, 24 а

E-mail: anna.mungalova@bk.ru

Если ранее школьный анализ лирики был сосредоточен главным образом на идейнотематическом комплексе произведения - его проблематике и жанровой специфике, то сегодня одним из актуальных подходов к освоению лирики в школе становится анализ формальных компонентов текста. Данный подход наиболее адекватен для изучения нетрадиционной, авангардной поэзии, ориентированной на формальный эксперимент, создающий ситуацию паритета формы и содержания. В настоящей статье предложен вариант школьного анализа современного авангардного лирического текста с точки зрения его символики. Материалом послужила лирика Ю. Шевчука - одного из наиболее ярких представителей русской рок-поэзии. Рассмотрены такие образы-символы, как путь, небо, сад, звезда. Определена их семантика и связь с поэтическим наследием русской лирики XIX-XX веков.

Ключевые слова: Ю. Шевчук, рок-поэзия, образ, символ, мотив, традиция.

\section{Для цитирования:}

Колмакова О. А., Мунгалова А. Н. Изучение поэзии Ю. Шевчука в школе // Вестник Бурятского государственного университета. Язык. Литература. Культура. 2019. Вып. 4. С. 49-53.

Одним из ведущих направлений современного школьного изучения лирического текста является исследование его поэтики, что обусловлено, в частности, требованиями к сдаче ЕГЭ по литературе. Данная статья посвящена анализу поэтики символа в стихотворениях Ю. Шевчука, чье творчество, наряду с произведениями В. Цоя, Д. Ревякина, К. Кинчева, Б. Гребенщикова, Н. О’Шей и др. формирует пространство текста русской рок-поэзии.

Поскольку рок-поэзия представляет собой одну из форм существования современной русской авангардной поэзии, многие исследователя обращали внимание именно на языковой строй ее текстов. Так, об иноязычной лексике в произведениях рок-поэзии писала К. В. Западная, о поэтике цвета - Ю. В. Маслова, о роли неологизмов - М. П. Сухих и др. Мы предлагаем рассмотреть символический строй текста современной рок-поэзии на материале творчества Ю. Шевчука. 
Изучение лирического произведения посредством анализа образов-символов позволяет, на наш взгляд, избежать частой ошибки учителя, от которой предостерегал еще В. П. Медведев: это «постановка десятков вопросов, которые подчас направляют ученика на прозаический пересказ текста, а главное - разрушают целостное восприятие стихотворения» [Медведев, 1985, с. 4].

Релевантность нашего анализа определяется также спецификой самой категории символа, являющегося универсальным поэтическим приемом. А. Ф. Лосев писал, что всякий символ указывает на некоторый предмет, выходящий за пределы его непосредственного содержания, то есть идейно-образно оформляет этот предмет. «Но, взятая сама по себе, идейная образность не есть символ. Чтобы быть символом, - пишет далее А. Ф. Лосев, — она должна указывать на нечто другое, что не есть она сама, и даже быть для этих других предметов законом их построения» [Лосев, 1976, с. 25]. Утверждая неисчерпаемость и многогранность символа, Лосев называет его «той обобщенной смысловой мощью предмета, которая, разлагаясь в бесконечный ряд, осмысливает собою и всю бесконечность частных предметов, смыслом которых она является» [там же].

Благодаря символизации в художественном произведении осуществляется выход к философской проблематике. Как писал Д. С. Лихачев, символы абстрактны и «прямо противоположны основным художественным тропам - метафоре, метонимии, сравнению, основанным на уподоблении, на живом и непосредственном восприятии мира» [Лихачев, 1979, с. 164]. Мысль о способности символов связывать реальность и потусторонний мир наиболее четко оформилась в работах теоретиков русского символизма. Так, Д. С. Мережковский называл символ «образом, явлением этого мира», изображенным так, что «сквозь него светится образ миров иных» [Мережковский, 1971, с. 257].

Символ в поэзии Ю. Шевчука - один из важнейших художественных приемов освоения реальности, средство восхождения от привычного обыденного мира в сферу метафизики. Анализируя текст песни Ю. Шевчука «Дождь», И. А. Авдеенко приходит к выводу о том, что поэт «экспериментирует с символом» за счет механизма «притягивания и рассеивания ассоциаций», что значительно расширяет художественное пространство текста, уводя в данном случае к библейским контекстам и превращая лирического героя в «человека-бога» [Авдеенко, 2010, с. 48].

Художественное сознание Ю. Шевчука сформировалось «на границе» двух эпох - советской и постсоветской, когда статус рок-поэзии кардинально изменился: из сферы искусства андеграунда рок-поэзия перекочевывает в пространство чуть ли не творческого «мейнстрима». Рок-поэзия как синтетическое искусство складывалась из трех компонентов: музыки, авторской индивидуальности и поэтического текста. На наш взгляд, музыка и авторская «харизма» играли определяющую роль в советский период существования рок-поэзии, когда она была искусством «подполья». На современном же этапе свободного существования рок-поэзии приоритетным становится сам поэтический текст. Неслучайно поэтому появление в творчестве рок-музыкантов именно стихотворений, а не «текстов» песен. Далее мы рассмотрим подборку «Стихов разных лет» Ю. Шевчука, напечатанных в альманахе «Русский міръ. Пространство и время русской культуры» (№ 2, 2009). 
Объединяющим в данной подборке является образ лирического героя, который сочетает в себе черты бунтаря-романтика и философа. Сквозными образамисимволами являются путь, сад, небо, звезда. Так, в стихотворении «Мы вечно в пути, мы - голодное где-то...» возникает образ пути, символика которого совпадает с традиционной философской — путь как «дорога жизни»: «Мы вечно в пути, мы - голодное где-то / Мы отчаянная, ненадежная жизнь. / За краюху безумного этого света / До последнего, парень, держись» [Шевчук, 2009, с. 29].

Как антитеза динамического образа пути-жизни в стихотворении возникает статичный образ могилы-пропасти: «Мы спасаем наш мир от дряни и порчи, / Заедая тоской и надеждою снег. / Мы стоим над могилою-пропастью, молча, / Наблюдая, как в вечность ползет человек» [Там же]. В словаре символов Х. Э. Керлота символика пропасти-бездны раскрывается следующим образом: «Бездна имеет зачаровывающий двойной смысл. С одной стороны - это символ смерти, с другой - символ зла. Эти два смысла неразрывно связаны друг с другом» [Керлот, 2004, с. 93]. Следовательно смыслом жизни становится постоянное преодоление смерти, символическая битва со смертью, на которую способен только бунтарь: «Мы в последнюю, ночную атаку / Поднимаем себя с живота, налегке» [Шевчук, 2009, с. 29].

Стихотворение «Вальс» проникнуто христианской символикой и содержит прямое обращение к Христу: «Покажи нам чудо, чтобы видно было многим, / Как перевоплощается в кровь твое вино» [Шевчук, 2009, с. 28]. Стихотворение посвящено теме творчества. Именно творчество позволяет лирическому герою «подыскать ключи / В сад», символизирующий Рай. И в то же время взгляд художника оценивает мир диалектически. Ю. М. Лотман писал о том, что поэзия имеет «свою систему синонимов и антонимов. “День" и “ночь", “жизнь" и “смерть” могут в поэтическом тексте быть синонимами» [Лотман, 2016, с. 483]. Так, в строке Шевчука «Бабка-повитуха - смерть, хоть что-нибудь скажи» жизнь (повитуха $=$ жизнедательница) и смерть становятся синонимами, чем утверждается идея противоречивости мира.

При анализе стихотворений Ю. Шевчука необходимо помнить, что «в лирике перед нами живая взволнованная человеческая речь, художественно организованная в целостную выразительную систему языка - стихотворную речь» $[9$, c. 175]. Лирический герой Шевчука эмоционален еще и потому, что автобиографичен, и особенно яркие эмоции автора ощутимы в произведениях на актуальную для него тему поэта и поэзии. В стихотворениях «По утрам я Моцарт...» и «Дуэль» создаются образы русских поэтов, которых Шевчук считает своими Alter Еgo. Данная позиция современного автора говорит о преемственности между русской классикой XIX-XX вв. и современным искусством.

За каждой строкой стихотворения «По утрам я Моцарт...» перед читателем встает образ одного из русских поэтов-классиков. Строки «По утрам я Моцарт, / По ночам Сальери» связаны с А. С. Пушкиным и его трагедией; далее следуют строки «Стал петлёю нотной / в потном Англетере», вызывающие в памяти образ С. А. Есенина; строки «Окна на Исаакий - / Купола под снегом» напоминают об А. А. Ахматовой, ее «Стихах о Петербурге»: «Вновь Исакий в облаченьи / Из литого серебра...». Строка «Вьюга замотала» отсылает к А. А. Блоку, его «Снежной маске» или поэме «Двенадцать». В финале лирический герой все-таки 
идентифицирует себя с Есениным: «По ночам я Сталин, / По утрам Есенин» [Шевчук, 2009, с. 33-34]. Основные символические образы этого стихотворения - день и ночь, в которых поэт раскрывает двойственную человеческую сущность, противоречивость его натуры.

Стихотворение «Дуэль» посвящено гибели А. С. Пушкина, вместе с которым уходит целая эпоха: «Темнело быстро, небо прятало войну, / Д'Аршиак с Данзасом втаптывали в снег / Барьер бессмертия, холодную луну, / Последний вздох и час, блестящий этот век...». Символика мотива дуэли в стихотворении связывается с образами войны и боя: «Все! Начали! К барьеру! К чёрту страх, / Пускай убьют, судьба моя со мной, / Поплыли облака, мундиры, пальцы на курках, / Рванули кони, жизнь сворачивалась в бой...». Дуэль Пушкина с Дантесом - это поединок поэта с судьбой: «Всё решено - дуэль, я не сверну, / Пускай потом прибьют гвоздём ко дну $<\ldots>$ На Чёрной речке, вечером, к пяти. / Я не сверну, и с рифмы не сойти...» [Шевчук, 2009, с. 35-36]. В мотиве бессмысленной смерти Пушкина Шевчук воплощает идею несовершенства мира.

Враждебность мира воплощается также в нетрадиционно негативной, авангардной символике образа звезды в стихотворении «Любовь, подумай обо мне»: «Когда огонь ударил в пляс, а звезды - иглы-палачи, / Когда судьба в урочный час орало плавит на мечи, / И ветер больше не живет, и падший ангел на коне, / И никого никто не ждет... / Любовь, подумай обо мне» [там же, с. 32]. Повторенная трижды фраза-рефрен «Любовь, подумай обо мне» и обращение «мой друг» уводят от ощущения безысходности и привносят в стихотворение мотив надежды.

При изучении поэзии Ю. Шевчука на уроках литературы нужно исходить из положения о двуплановости символической образности в ней. С одной стороны, в стихотворениях Ю. Шевчука обнаруживается ряд традиционных для русской поэзии XIX-XX веков образов-символов: путь, небо, сад, звезда. С другой стороны, экспериментальный характер символики текстов Шевчука выражает особенности мировоззрения поэта, являющегося ярким представителем современного русского авангарда.

\section{Литература}

1. Авдеенко И. А. Символ, концепт, текст: пространство эксперимента // Ученые записки Комсомольского-на-Амуре государственного технического университета. 2010. № 1. T. 2. С. 45-48.

2. Керлот Х. Э. Словарь символов. М.: REFL-BOOK, 1994. 603 c.

3. Лихачев Д. С. Поэтика древнерусской литературы. М.: Наука, 1979. 352 с.

4. Лосев А. Ф. Проблема символа и реалистическое искусство. М.: Искусство, 1976. $367 \mathrm{c}$.

5. Лотман Ю. М. Структура художественного текста. Анализ поэтического текста. СПб.: Азбука, Азбука-Аттикус, 2016. 704 с.

6. Медведев В. П. Изучение лирики в школе: кн. для учителя. М.: Просвещение, 1985. $208 \mathrm{c}$.

7. Мережковский Д. С. Акрополь. М.: Кн. палата, 1991.351 с.

8. Ожегов С. И. Словарь русского языка / под ред. Н. Ю. Шведовой. М.: Русский язык, 1987.750 с.

9. Словарь литературоведческих терминов / ред.-сост. Л. И. Тимофеев и С. В. Тураев. М.: Просвещение, 1974. 509 с. 
10. Шевчук Ю. Стихи разных лет // Русский міръ. Пространство и время русской культуры. 2009. № 2. С. 28-38.

\section{STUDYING THE POETRY OF YURI SHEVCHUK AT SCHOOL}

(C) Oksana A. Kolmakova

doctor of Sciences in Philology, associate professor of the Russian and foreign literature department of Institute of Philology and Mass Communications

Dorzhi Banzarov Buryat State University

24-a, Smolina Str., Ulan-Ude, 670000 Russia

(C) Anna N. Mungalova

underground student of Institute of Philology, foreign languages

and Mass Communications

Dorzhi Banzarov Buryat State University

24-a, Smolina Str., Ulan-Ude, 670000 Russia

Earlier the school analysis of the lyrics was mainly focused on the ideological and thematic complex of the work, its problematics and genre specificity. Today one of the current approaches to the development of lyrics in school is the analysis of the formal components of the text. This approach is most appropriate for studying unconventional, avant-garde poetry, focused on a formal experiment. This article proposes a variant of the school analysis of a modern avant-garde lyric text from the point of view of its symbolism. The material was the lyrics of Yuri Shevchuk, one of the most prominent representatives of Russian rock poetry. Considered such images-symbols, as the path, the sky, the garden, the star. Their semantics and connection with the poetic heritage of the Russian poetry of the XIXXX centuries are defined.

Keywords: Yuri Shevchuk, rock poetry, image, symbol, motif, tradition. 